\title{
Microzooplankton grazing activity in the temperate and sub-tropical NE Atlantic: summer 1996
}

\author{
Claire E. Stelfox-Widdicombe ${ }^{1, *}$, Elaine S. Edwards ${ }^{1}$, Peter H. Burkill ${ }^{1}$, \\ Michael A. Sleigh ${ }^{2}$ \\ ${ }^{1}$ Marine Laboratory, Prospect Place, West Hoe, Plymouth PL1 3DH, United Kingdom \\ ${ }^{2}$ School of Biological Sciences, University of Southampton, Bassett Crescent East, Southampton SO16 7PX, United Kingdom
}

\begin{abstract}
The role of microzooplankton herbivory in the fate of phytoplankton production was quantified within 2 biologically contrasting water masses in the NE Atlantic during the summertime. Seawater dilution experiments were conducted to quantify phytoplankton growth and losses due to grazing during 2 Lagrangian surveys, at $60^{\circ} \mathrm{N}$ and $37^{\circ} \mathrm{N}$, in the vicinity of the $20^{\circ} \mathrm{W}$ meridian. Phytoplankton growth rates were higher during the northerly study at $60^{\circ} \mathrm{N}$ (mean $1.54 \mathrm{~d}^{-1}$ ) than at the southerly study, $37^{\circ} \mathrm{N}$. Estimates of phytoplankton growth during the southerly study were corrected for photoadaptation, and the mean growth rate was $0.62 \mathrm{~d}^{-1}$. The day-to-day pattern of phytoplankton mortality due to microzooplankton grazing was similar to the growth rates, with higher values recorded in the northerly study $\left(1.25 \mathrm{~d}^{-1}\right)$ and lower values at the southerly site $\left(0.43 \mathrm{~d}^{-1}\right)$. In the northerly waters, microzooplankton consumed up to $77 \% \mathrm{~d}^{-1}$ of the chlorophyll standing stock, while microzooplankton herbivory at the southerly site accounted for $<44 \% \mathrm{~d}^{-1}$ of the chlorophyll stocks. Microzooplankton grazing represented a carbon flux of between 3 and $37 \mu \mathrm{C} \mathrm{l}^{-1} \mathrm{~d}^{-1}$, with highest values found in the eutrophic northerly waters. The microzooplankton community were numerically dominated by small heterotrophic nanoflagellates (HNAN) $\left(0.7\right.$ to $4.2 \times 10^{5}$ cells $\left.^{-1}\right)$. However in terms of the microzooplankton biomass, heterotrophic dinoflagellates dominated at the northerly site $\left(5.6 \mu \mathrm{g} \mathrm{Cl}{ }^{-1}\right)$ while the HNAN $\left(1.1 \mu \mathrm{g} \mathrm{Cl}^{-1}\right)$ and oligotrich ciliates $\left(0.7 \mu \mathrm{g} \mathrm{Cl}^{-1}\right)$ were more important at the southerly station. Tintinnids and 'other' ciliates contributed less to the total microzooplankton abundance or biomass. We conclude that microzooplankton formed a significant component of the food web in the NE Atlantic and were important controllers of phytoplankton production, particularly in temperate waters, during this investigation period. Our data suggest that microzooplankton grazing did not control the picoplankton production in the oligotrophic sub-tropical NE Atlantic during the summer, and this may be attributable to the dominance of Prochlorococcus spp.
\end{abstract}

KEY WORDS: Microzooplankton grazing - Seawater dilution · Microzooplankton community • Chlorophyll $\cdot$ NE Atlantic

\section{INTRODUCTION}

Microzooplankton, defined herein as heterotrophic organisms between 2 and $200 \mu \mathrm{m}$ in size, form a significant proportion of total zooplankton biomass in many oceanic environments. They are a taxonomically diverse group that includes ciliates, flagellates, dino-

*E-mail: clst@pml.ac.uk flagellates, sarcodines and small metazoans (Capriulo et al. 1991). Estimates of their grazing impact indicate that they can control phytoplankton production (e.g. Gifford 1988, Burkill et al. 1993, Verity et al. 1993) and play a significant role in the fate of bacteria (e.g. Weisse \& Scheffel-Möser 1991) and in the regeneration of nutrients (e.g. Goldman et al. 1987). Ciliates and dinoflagellates often form a significant part of the diets of larger zooplankton, such as copepods (Atkinson 1996), and therefore provide an important trophic link 
between small prey and larger predators (Sherr et al. 1986). Microzooplankton are able to select food, based on size and nutritional value (Anderson 1997), which coupled with a rapid population response to changes in food abundance, allow them to play a significant role in structuring plankton communities and determining the fate of phytoplankton production within the euphotic zone and its export from it (Michaels \& Silver 1988, Strom \& Strom 1996, Wassmann 1998).

The NE Atlantic Ocean is characterised by large seasonal variations in phytoplankton biomass. The most notable event is the spring phytoplankton bloom, which develops near $40^{\circ} \mathrm{N}$ during April and May and proceeds towards 60 to $70^{\circ} \mathrm{N}$ by June (Ducklow \& Harris 1993, Verity et al. 1993). High concentrations of nitrate supplied during winter mixing combined with thermal stratification and increased light levels enable the spring bloom to develop. Uncoupling between production and consumption leads to accumulation of biogenic material in surface waters as larger phytoplankton cells, particularly diatoms and dinoflagellates, become important (Colebrook 1982, Joint et al. 1993). During the summer, post-bloom phytoplankton are dominated by nanoplankton, which can account for more than $50 \%$ of the seasonal primary production (Ducklow \& Harris 1993). In contrast, in the sub-tropical region to the south of $40^{\circ} \mathrm{N}$, oligotrophic conditions prevail during the summer and low phytoplankton production rates are dominated by picoplankton ( 0.2 to $2 \mu \mathrm{m})$.

The role of microzooplankton herbivory and the fate of phytoplankton production in the NE Atlantic was studied during the Joint Global Ocean Flux Study (JGOFS) North Atlantic Bloom Experiment (NABE) in 1989 and the Office of Naval Research (USA) Marine Light Mixed Layer (MLML) programme in 1991. These studies demonstrated that microzooplankton were important controllers of the fate of phytoplankton production in surface waters between 47 and $60^{\circ} \mathrm{N}$, and between 20 and $21^{\circ} \mathrm{W}$. Results from experiments using the dilution technique of Landry \& Hassett (1982) showed that microzooplankton herbivory accounted for up to $115 \%$ of daily phytoplankton production (Burkill et al. 1993, Verity et al. 1993, Gifford et al. 1995). However, these studies focused on the spring and summer phytoplankton communities in northern, eutrophic waters and did not investigate the role of microzooplankton grazing in the southerly, oligotrophic region of the NE Atlantic. The current study compares the role of microzooplankton grazing activity within 2 biologically contrasting water masses in the temperate and sub-tropical NE Atlantic during the summer period. In particular, this study examines the extent to which production from contrasting plankton communities can be fully utilised by microzooplankton consumption. This work forms part of the UK Plankton Reactivity in the Marine Environment (PRIME) programme, which is outlined by Savidge \& Williams (2000). A more detailed description of the phytoplankton community is given by Tarran et al. (2001).

\section{MATERIALS AND METHODS}

Study location. Experiments to investigate the impact of microzooplankton grazing on phytoplankton stocks in the NE Atlantic were conducted aboard RRS 'Discovery' on Cruise D221 during June/July 1996. The dilution technique (Landry \& Hassett 1982) was used to estimate phytoplankton growth and mortality due to microzooplankton herbivory. The cruise formed part of the PRIME Special Topic programme and involved 2 Lagrangian studies in contrasting oceanic sites. The 2 studies were centred in the vicinity of $60^{\circ} \mathrm{N}, 20^{\circ} \mathrm{W}$ during June and $37^{\circ} \mathrm{N}, 19^{\circ} \mathrm{W}$ during July. The northerly Lagrangian study formed part of a sulphur hexafluoride $\left(\mathrm{SF}_{6}\right)$ tracer-release experiment within a mesoscale eddy (Martin et al. 1998) which enabled an essentially coherent body of water to be sampled over a $9 \mathrm{~d}$ period. A detailed description of the $\mathrm{SF}_{6}$ experiment can be found in Law et al. (2001). Experiments were carried out between 18 and 27 June within the eddy, and on 28 June a comparative experiment was conducted outside the $\mathrm{SF}_{6}$ tracer patch. During the southerly study, an Argos buoy was drogued at $14 \mathrm{~m}$ and followed for $7 \mathrm{~d}$. Samples were taken close to the buoy and 5 grazing experiments were conducted between 11 and 18 July.

Experimental set-up. Seawater was collected predawn from a depth corresponding to the $33 \%$ surface irradiance (determined from daily irradiance profiles) using 301 acid-clean Go-Flo bottles. One exception to this was on 27 June, when experimental water was collected from the $55 \%$ surface-irradiance depth. Filtered seawater was prepared by draining water, via silicone tubing, from the Go-Flo bottles into $10 \mathrm{l}$ polycarbonate carboys and then filtered, using a peristaltic pump, through a $0.2 \mu \mathrm{m}$ Gelman Supor-capsule filter into 2.31 polycarbonate bottles. Prior to use, capsule filters were soaked overnight in $10 \% \mathrm{HCl}$ and flushed with $10 \mathrm{l}$ of Nanopure water; the first $10 \mathrm{l}$ of filtrate were discarded to prevent contamination of the experimental water. Unfiltered seawater was gently siphoned directly from the Go-Flo bottles using silicone tubing (fitted with a $200 \mu \mathrm{m}$ mesh bag to remove mesozooplankton predators) into the 2.31 incubation bottles. The tubing end with the mesh bag was inserted below the water line in each bottle to ensure negligible bubble formation (which could damage the fragile microzooplankton). Each experiment consisted of a series of 4 dilution lev- 
els, set up in triplicate, which were nominally at concentrations of $0.1,0.4,0.7$ and 1.0 that of the ambient seawater. Although nutrients are often routinely added during dilution experiments (e.g. Landry \& Hassett 1982, Landry et al. 1995) to prevent nutrient limitation of phytoplankton growth during the $24 \mathrm{~h}$ incubation period, we chose not to do so in our experiments in order to avoid deleterious effects on microzooplankton numbers (Gifford 1988) and on phytoplankton growth (Lessard \& Murrell 1998). All tubing, filtration apparatus and polycarbonate containers were cleaned with $10 \% \mathrm{HCl}$ and thoroughly rinsed with Nanopure water and filtered seawater prior to each experiment. In addition, during set-up, the carboys and experimental bottles were covered with black plastic bags to minimise exposure to artificial light.

From each experimental bottle, sub-samples were taken for the determination of initial chlorophyll concentration. Additionally, a $300 \mathrm{ml}$ sample was taken from each of the undiluted bottles to determine the microzooplankton, including the heterotrophic nanoflagellate (HNAN), community composition. Each bottle was carefully re-filled to the same dilution level and tightly capped to exclude any air bubbles. All bottles were then placed in an on-deck incubator, which was cooled by flowing surface water and covered with a neutral-density screen to mimic in situ light conditions, for $24 \mathrm{~h}$. To check that experimental water was incubated under appropriate light conditions, flow cytometric counts were made on undiluted samples at the beginning and end of each experiment to monitor that the chlorophyll content per cell had not altered as a result of photoadaptation (Perry et al. 1981). At the end of each experiment, samples were taken from each bottle for the determination of total chlorophyll. The samples were filtered onto $0.2 \mu \mathrm{m}$ polycarbonate filters and extracted in $10 \mathrm{ml}$ of $90 \%$ acetone at $-20^{\circ} \mathrm{C}$ overnight. Analysis for chlorophyll a was made on board ship using a sensitive fluorometer (Aiken 1981) calibrated against HPLC-determined chlorophyll $a$. Chlorophyll concentrations measured in the $t_{0}$ (time zero) subsamples were used to determine the actual dilution level (as fraction of undiluted seawater) in each bottle.

To determine the community structure of the microzooplankton in the initial undiluted experimental water, $250 \mathrm{ml}$ subsamples were fixed in acid Lugol's solution ( $1 \%$ final concentration) and stored in the dark until analysis in the laboratory by inverted settlement microscopy (Utermöhl 1958). Losses of oligotrich ciliates may occur during preservation using this method, thereby underestimating ciliate abundance and total microzooplankton biomass (Stoecker et al. 1994a). Small volumes (up to $100 \mathrm{ml}$ ) were concentrated by sedimentation for $24 \mathrm{~h}$, and all heterotrophic individuals $<200 \mu \mathrm{m}$ (excluding the heterotrophic nanoflagellates $<20 \mu \mathrm{m}$ ) were identified and enumerated at $\times 300$ magnification using an Olympus inverted microscope. As it is not possible to distinguish heterotrophic nanoflagellates (HNAN) from autotrophic forms using ordinary light microscopy, a separate method was used to enumerate the HNAN (see below). The microzooplankton fraction was divided into 4 main categories: dinoflagellates, oligotrich ciliates, tintinnids and 'other' ciliates. Metazoans (copepod nauplii $<190 \mu \mathrm{m}$ in length) and sarcodines (acantharians, radiolarians and foraminiferans) were enumerated, but because of their low abundance and the low sensitivity of this method, these data are not presented. The microzooplankton were sized using image-analysis, whereby heterotrophic cells were traced using a computer programme and, assuming appropriate geometric shapes, volumes were calculated from cell area and maximum length. The biovolume of each cell was then converted into carbon using conversion factors of

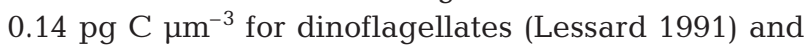

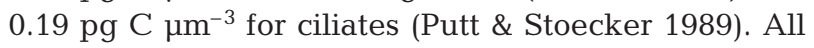
ciliated protozoans were classified as potential herbivores, except for the ciliate Mesodinium spp., which was regarded as functionally autotrophic and therefore not quantified. Heterotrophic dinoflagellates were distinguished from autotrophic and mixotrophic taxa by the absence of chlorophyll fluorescence in fresh samples, which were gently concentrated onto a $20 \mu \mathrm{m}$ mesh, transferred to a counting chamber, and examined by epifluorescence inverted-microscopy at sea. Therefore, only strictly heterotrophic dinoflagellates $>20 \mu \mathrm{m}$ in size were enumerated during this study.

To quantify the $<20 \mu \mathrm{m}$-sized HNAN (which includes heterotrophic dinoflagellates), initial undiluted water samples of between 30 and $50 \mathrm{ml}$ were fixed with $0.3 \%$ (final concentration) glutaraldehyde. The fixed sample was then stained with diamidino-2phenylindole (DAPI) and proflavine (final concentration $5 \mu \mathrm{g} \mathrm{ml}^{-1}$ ), mounted on $0.8 \mu \mathrm{m}$ black polycarbonate filters (Sieracki et al. 1993, Stoecker et al. 1994b), and kept frozen at $-20^{\circ} \mathrm{C}$ until analysis by epifluorescence microscopy ( $\times 900$ magnification). Heterotrophic cells, which were distinguished from autotrophic taxa by the absence of chlorophyll autofluorescence, were enumerated and sized using an ocular micrometer. Cell volumes were calculated, assuming a prolate ellipsoid shape, from average dimensions of 30 to 50 cells measured for each morphotype using our image-analysis system. Biovolume was then converted to carbon using a factor of $0.14 \mathrm{pg} \mathrm{C} \mathrm{\mu m}^{-3}$ for heterotrophic dinoflagellates (Lessard 1991) and $0.22 \mathrm{pg} \mathrm{C}$ $\mu^{-3}$ for nanoflagellates (Børsheim \& Bratbak 1987). HNAN between 5 and $20 \mu \mathrm{m}$ were enumerated during the northerly study, and cells between 2 and $20 \mu \mathrm{m}$ were quantified at the southerly site. 
Microzooplankton grazing was determined from measurements of the apparent growth rate of phytoplankton that were made assuming the exponential growth equation of Landry \& Hassett (1982):

$$
P_{t}=P_{0} \mathrm{e}^{(k-c g) t}
$$

or

$$
\frac{1}{t} \ln \left(\frac{P_{t}}{P_{0}}\right)=k-c g
$$

where $P_{0}$ and $P_{t}$ are the initial and final concentrations of chlorophyll a respectively; $k$ and $g$ are the instantaneous coefficients of phytoplankton growth and grazing mortality respectively; and $C$ is the concentration of the prey and predator populations relative to ambient seawater. Values of growth and mortality were determined from linear regression analysis between the apparent growth rate of chlorophyll $a$ and the fraction of undiluted seawater. The proportion of initial chlorophyll standing stock $\left(P_{i}\right)$ turned over, as $\% \mathrm{~d}^{-1}$, by the microzooplankton was calculated according to:

$$
P_{\mathrm{i}}=1-\mathrm{e}^{-g} \times 100
$$

while microzooplankton ingestion rates $(I R)$ were estimated from:

$$
I R=P_{\mathrm{i}} \times P_{0} \times(\mathrm{C}: \mathrm{chl} a)
$$

\section{RESULTS}

\section{Environmental conditions}

The northerly study was centred within a mesoscale eddy, which was characterised as a cold-core feature with a strong anticyclonic circulation that extended approximately $40 \mathrm{~km}$ across (for a more detailed description see Martin et al. 1998, 2001). The eddy had a shallow mixed layer (average of $20 \mathrm{~m}$ ), a sea-surface temperature of approximately $10.4^{\circ} \mathrm{C}$, and an average chlorophyll a concentration of $1.1 \mu \mathrm{g} \mathrm{l^{-1 }}$. Approximately half of the chlorophyll biomass was concentrated in cells $>5 \mu \mathrm{m}$, and an average of $72 \%$ of the daily phytoplankton production was attributed to the $>5 \mu \mathrm{m}$ fraction (Rees et al. 2001) which coincided with a bloom of the coccolithophore Coccolithus pelagicus. Most of the daily phytoplankton production was restricted to the surface mixed layer; approximately $12 \%$ ( $\mathrm{SD}=8 \%$ ) occurred below the mixed layer (Donald et al. 2001). Nanophytoplankton were also abundant, while the contribution of diatoms and autotrophic dinoflagellates to the total phytoplankton standing stock was low (Tarran et al. 2001). Surface concentrations of new nutrients were high, and maximum concentrations, e.g. nitrate $\left(8.3 \mu \mathrm{mol} \mathrm{l^{-1 }}\right)$ and phosphate $\left(0.5 \mu \mathrm{mol} \mathrm{l}^{-1}\right)$, were recorded in the centre of the eddy
(Woodward \& Rees 2001). During the initial period of the study, an increase in the surface temperature was mirrored by a decrease in nitrate and phosphate (Woodward \& Rees 2001), and bacterial abundance (Zubkov et al. 2001). However, a storm on 24 June resulted in upwelling of cool, nutrient-rich water. Thereafter bacterial concentrations increased at a rate of $8 \% \mathrm{~d}^{-1}$ (Zubkov et al. 2001), while the mesozooplankton biomass $\left(6.7 \mu \mathrm{g} \mathrm{C}^{-1}\right)$ showed little change and no diurnal activity (Head et al. 1999). Outside the eddy, the surface mixed layer was deeper and the seasurface temperature was approximately $1^{\circ} \mathrm{C}$ warmer. Lower chlorophyll a concentrations were mirrored by a reduction in the phytoplankton standing stock, which did not contain C. pelagicus and had lower nanophytoplankton concentrations (Tarran et al. 2001).

In contrast to the northerly waters, the southerly site was characterised by oligotrophic conditions, warmer surface temperatures $\left(>20^{\circ} \mathrm{C}\right)$, a deeper surface mixed layer (average $25 \mathrm{~m}$ ) and depleted nutrient levels (e.g. $<0.05 \mathrm{mmol} \mathrm{l}^{-1}$ nitrate, $0.02 \mu \mathrm{mol} \mathrm{l^{-1 }}$ phosphate) (Donald et al. 2001). Chlorophyll concentrations were low $\left(<0.1 \mu \mathrm{g} \mathrm{l}^{-1}\right)$, and a pronounced deep chlorophyll maximum was observed at around $70 \mathrm{~m}$. Phytoplankton standing stocks were much lower, approximately onethird of the stocks measured in the northerly study, and were dominated by picoplankton (Tarran et al. 2001), which accounted for up to $71 \%$ of the total phytoplankton production (Donald et al. 2001). Daily production rates were also lower, but a considerable proportion (average $69 \%, \mathrm{SD}=14 \%$ ) occurred below the surface mixed layer. High values of the depth integrated $f$-ratio were recorded due to the deep euphotic zone depth and light penetration of the nitracline, indicating that nitrate was important for phytoplankton production rather than nutrient regeneration, which is more typical of oligotrophic environments (Donald et al. 2001). Mesozooplankton biomass was lower, in comparison with the temperate waters, and a distinct diel cycle was recorded whereby biomass was 2.2 and $1.4 \mu \mathrm{g} \mathrm{C}^{-1}$ for night and day periods respectively (Head et al. 1999). Weakening of the thermocline during the study and a transition towards higher salinity water on 14 July suggested that the drogued buoy was drifting through different water masses.

\section{Phytoplankton growth and mortality due to grazing}

Table 1 summarises the estimates of phytoplankton growth and grazing coefficients from the dilution experiments conducted during the cruise, together with associated environmental variables. Estimates of phytoplankton growth rates $(k)$ were higher in the northerly waters (average $1.54 \mathrm{~d}^{-1}, \mathrm{SD}=0.18$ ) com- 
pared to the southerly site (average $0.93 \mathrm{~d}^{-1}, \mathrm{SD}=$ 0.22). However, evidence from the flow cytometry counts taken from undiluted samples suggest that photoadaptation occurred in the experiments conducted during the southerly study, while those conducted during the northerly study did not show any evidence of photoadaptation. During the northerly study, the apparent phytoplankton growth showed little change with time, although the highest growth rate, equivalent to 2.5 doublings $\mathrm{d}^{-1}$, was recorded on 23 June, just prior to a storm. After the storm, growth rates corresponded to slightly more than 2 doublings $\mathrm{d}^{-1}$. The experiment conducted outside the eddy showed that phytoplankton growth rates were similar to those within the eddy. In the southerly waters, growth rates were more variable over the $7 \mathrm{~d}$ and decreased from 1.14 to $0.70 \mathrm{~d}^{-1}$. However, the flow cytometric data from the southerly study showed an increase in the chlorophyll content per cell (measured as the mean red fluorescence per cell) for the 3 main picoplankton groups, Synechococcus spp. Prochlorococcus spp. and the picoeukaryotes, due to photoadaptation. This led to an overestimate of the apparent growth rate of phytoplankton. From the flow cytometric counts we determined the total red fluorescence of the picoplankton and used this as a proxy for the picoplankton chlorophyll $\left(\mu \mathrm{g} \mathrm{l}^{-1}\right)$, which was assumed to be $71 \%$ of our initial chlorophyll biomass (Donald et al. 2001). Using this method, we calculated a correction factor for estimating the chlorophyll biomass at the end of our experiments and hence determine that phytoplankton growth was overestimated by approximately $32 \%$ during the southerly study. By taking this into account, we predict that growth rates $\left(k_{c}\right)$ would have ranged from 0.43 to $0.79 \mathrm{~d}^{-1}$ (Table 1). Rates of phytoplankton loss due to microzooplankton grazing $(g)$ were also higher during the northerly study (avg. $1.25 \mathrm{~d}^{-1}, \mathrm{SD}=0.22$ ), and there was no significant difference in grazing rates between the centre of the eddy and the area outside. In the southerly waters, grazing averaged $0.43 \mathrm{~d}^{-1}(\mathrm{SD}=$ 0.1 ) and followed the same pattern as estimates of growth, whereby rates decreased with time.

\section{Microzooplankton community structure}

The microzooplankton communities in the undiluted experimental water also showed distinct differences between the 2 study sites. The total concentration of microzooplankton (including the heterotrophic nano-

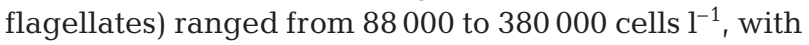
the HNAN contributing up to $99 \%$ of the total abundance. However in terms of biomass, the small flagellates contributed, on average, up to one-third of the total microzooplankton biomass at the northerly site, whilst in the southerly waters the HNAN accounted for almost half the total biomass. HNAN abundance and biomass are displayed in Fig. 1 and show that during the northerly study their numbers and carbon biomass (5 to $20 \mu \mathrm{m}$ ) were highest on $23 \mathrm{June}\left(361 \mathrm{ml}^{-1}, 5.18 \mu \mathrm{g}\right.$ $\mathrm{C}^{-1}$ ), before the storm. Outside the eddy, HNAN abundance was lower $\left(102 \mathrm{ml}^{-1}\right)$, and was similar to the concentrations ( 2 to $20 \mu \mathrm{m}$ ) recorded at the southerly site $\left(116 \mathrm{ml}^{-1}, \mathrm{SD}=21\right)$. HNAN biomass in the southerly waters was also low $\left(\mu \mathrm{g} \mathrm{Cl} \mathrm{l}^{-1}, \mathrm{SD}=0.1\right)$.

The microzooplankton community (determined from the Lugol-fixed samples) was composed principally of dinoflagellates and oligotrich ciliates, with tintinnids and 'other' ciliates present in lower concentrations. Heterotrophic dinoflagellates dominated the assem-

Table 1. Specific growth $(k)$ and grazing $(g)$ coefficients determined from dilution experiments, and summary of environmental conditions. $k_{c}$ : the growth coefficient corrected for photoadaptation $( \pm 95 \%$ confidence intervals $) ;$ r: correlation coefficient of linear regression between apparent phytoplankton growth rate and dilution factor, $\left({ }^{*} \mathrm{p}<0.01,{ }^{* *} \mathrm{p}<0.001\right)$. Initial chlorophyll $a$ (chl a) was determined fluorometrically for experimental $(<200 \mu \mathrm{m})$ water; experimental depth is equivalent to the $33 \%$ irradiance level except where noted otherwise; $T$ : in situ temperature; ML: surface mixed-layer depth; EZ: euphotic-zone depth; -: no evidence of photoadaptation

\begin{tabular}{|c|c|c|c|c|c|c|c|c|c|c|c|}
\hline $\begin{array}{l}\text { Date } \\
\text { (1996) }\end{array}$ & $\begin{array}{c}\text { Latitude } \\
{ }^{\circ} \mathrm{N}\end{array}$ & $\begin{array}{l}\text { Longitude } \\
{ }^{\circ} \mathrm{W}\end{array}$ & $\begin{array}{l}\text { Growth, } \\
k\left(\mathrm{~d}^{-1}\right)\end{array}$ & $\begin{array}{l}\text { Growth, } \\
k_{c}\left(\mathrm{~d}^{-1}\right)\end{array}$ & $\begin{array}{c}\text { Grazing, } \\
g\left(\mathrm{~d}^{-1}\right)\end{array}$ & $\mathrm{r}$ & $\begin{array}{l}\text { Initial chl a } \\
\quad\left(\mu \mathrm{g}^{-1}\right)\end{array}$ & $\begin{array}{l}\text { Experimental } \\
\text { depth }(\mathrm{m})\end{array}$ & $\begin{array}{c}T \\
\left({ }^{\circ} \mathrm{C}\right)\end{array}$ & $\begin{array}{l}\mathrm{ML} \\
(\mathrm{m})\end{array}$ & $\begin{array}{l}E Z \\
(\mathrm{~m})\end{array}$ \\
\hline 22 Jun & 59.201 & 20.122 & $1.24( \pm 0.29)$ & - & $0.89( \pm 0.32)$ & $0.71^{*}$ & $1.20( \pm 0.1)$ & 15 & 10.5 & 20 & 32 \\
\hline 23 Jun & 58.968 & 20.021 & $1.70( \pm 0.16)$ & - & $1.31( \pm 0.19)$ & $0.92^{* *}$ & $1.26( \pm 0.02)$ & 15 & 10.9 & 17 & 32 \\
\hline 25 Jun & 59.143 & 20.733 & $1.61( \pm 0.25)$ & - & $1.48( \pm 0.47)$ & $0.95^{* *}$ & $0.94( \pm 0.04)$ & 15 & 10.7 & 16 & 30 \\
\hline 27 Jun & 58.988 & 20.668 & $1.51( \pm 0.12)$ & - & $1.25( \pm 0.18)$ & $0.91^{* *}$ & $1.08( \pm 0.11)$ & $5^{a}$ & 10.8 & 28 & 32 \\
\hline $28 \mathrm{Jun}$ & 59.093 & 19.448 & $1.62( \pm 0.32)$ & - & $1.34( \pm 0.35)$ & $0.87^{* *}$ & $0.61( \pm 0.05)$ & 15 & 11.4 & 34 & 60 \\
\hline $11 \mathrm{Jul}$ & 37.008 & 19.001 & $1.09( \pm 0.14)$ & 0.79 & $0.57( \pm 0.19)$ & $0.93^{* *}$ & $0.05( \pm 0.004)$ & 25 & 20.3 & 29 & 108 \\
\hline $13 \mathrm{Jul}$ & 36.922 & 19.212 & $1.14( \pm 0.21)$ & 0.73 & $0.54( \pm 0.24)$ & $0.77^{*}$ & $0.06( \pm 0.01)$ & 25 & 20.2 & 23 & 120 \\
\hline $15 \mathrm{Jul}$ & 36.691 & 19.225 & $0.80( \pm 0.07)$ & 0.52 & $0.36( \pm 0.09)$ & $0.89^{* *}$ & $0.07( \pm 0.002)$ & 25 & 20.4 & 26 & 106 \\
\hline $17 \mathrm{Jul}$ & 36.319 & 19.150 & $0.70( \pm 0.07)$ & 0.43 & $0.26( \pm 0.02)$ & $0.71^{*}$ & $0.06( \pm 0.002)$ & 25 & 20.8 & 22 & 108 \\
\hline
\end{tabular}




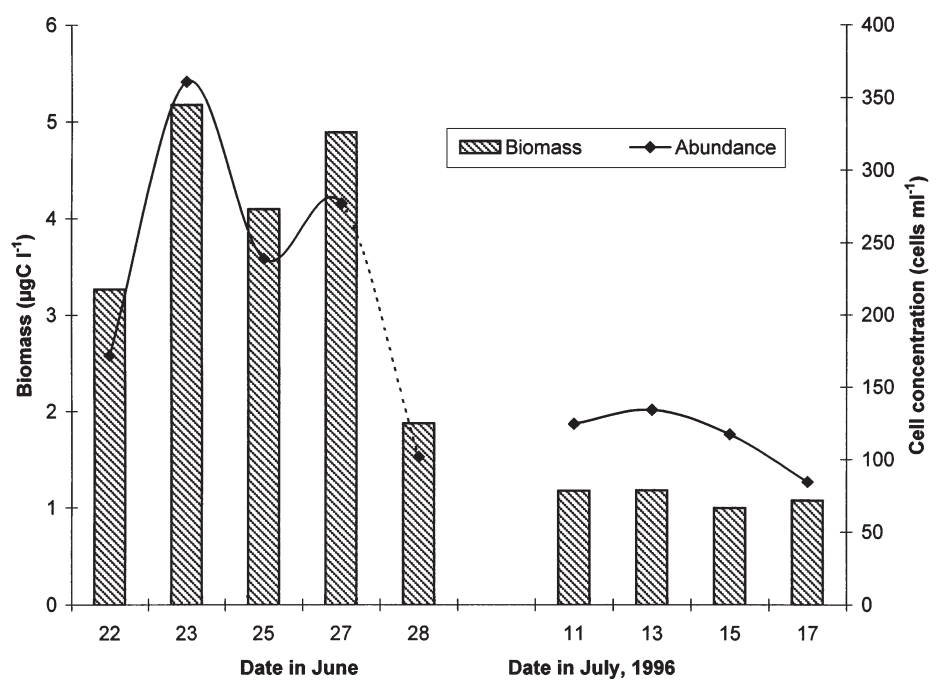

Fig. 1. Average heterotrophic nanoflagellate (HNAN) abundance and biomass concentrations in initial experimental water

blage during the northerly study in terms of abundance and biomass (Fig. 2), whilst oligotrich ciliates were generally more important at the southerly station. Total cell numbers (excluding the HNAN) were similar within the eddy, and averaged 17330 cells $1^{-1}$, whilst outside the eddy abundance was lower $\left(12625 \mathrm{l}^{-1}\right)$. In the southerly region, abundance of the microzooplankton fraction was lower with an average concentration of 2400 ind. $\mathrm{l}^{-1}$. In terms of their biomass, values recorded within the eddy ranged between 8 and $13 \mu \mathrm{g}$ $\mathrm{C}^{-1}$, and followed a similar pattern to the HNAN biomass, with highest values recorded on 23 June. Biomass of the microzooplankton was also lower outside the eddy $\left(5 \mu \mathrm{g} \mathrm{C}^{-1}, \mathrm{SD}\right.$ $=0.5$ ). As observed with the HNAN, low biomass values $\left(1 \mu \mathrm{g} \mathrm{Cl}^{-1}, \mathrm{SD}=0.4\right)$ were associated with the southerly study.

The mean cellular carbon of the microzooplankton, excluding the HNAN (Fig. 3) demonstrates that at the northerly site the dinoflagellates and oligotrichs were of a similar size and suggests that within the eddy the same community was sampled, despite the disruption of the storm. Size differences, inferred by the mean cellular carbon per cell, in the 'other' ciliates and tintinnids may be a reflection of their low abundance and reduced accuracy of the counting method. However, at the southerly site, relatively large dinoflagellates and oligotrichs appear to be replaced by smaller individuals with time, while 'other' ciliates may have increased in size. Despite low tintinnid abundances, those recorded were clearly dominated by larger individuals.

\section{DISCUSSION}

This study has illustrated distinct differences in the microzooplankton communities and their herbivorous impact on the phytoplankton stocks associated with the temperate and subtropical regions of the NE Atlantic during the summer. Our findings reflect the contrasting environmental conditions encountered at the northerly and southerly sites.

Conditions during our northerly study indicated that the phytoplankton were in a midbloom phase, because of high concentrations of new nutrients and a dominance of coccolithophores (Weeks et al. 1993). It seems likely that Verity et al. (1993) sampled mid- to latebloom conditions at $47^{\circ} \mathrm{N}$ during spring 1989 , while Burkill et al. (1993) sampled late-bloom conditions at $60^{\circ} \mathrm{N}$ and post-bloom conditions at $47^{\circ} \mathrm{N}$ during the summer 1989 (Weeks et al. 1993). The MLML study site was occupied during both the initial phase of the spring bloom (when Phaeocystis spp. and small diatoms dominated the phytoplankton) during spring 1991 and the post-bloom phase during summer 1991 (Gifford et al. 1995). Therefore, our northerly study falls within the range of conditions previously described in the temperate NE Atlantic.

The microzooplankton were abundant in the northerly waters and were dominated by HNAN and dinoflagellates; this is in keeping with the community pre-

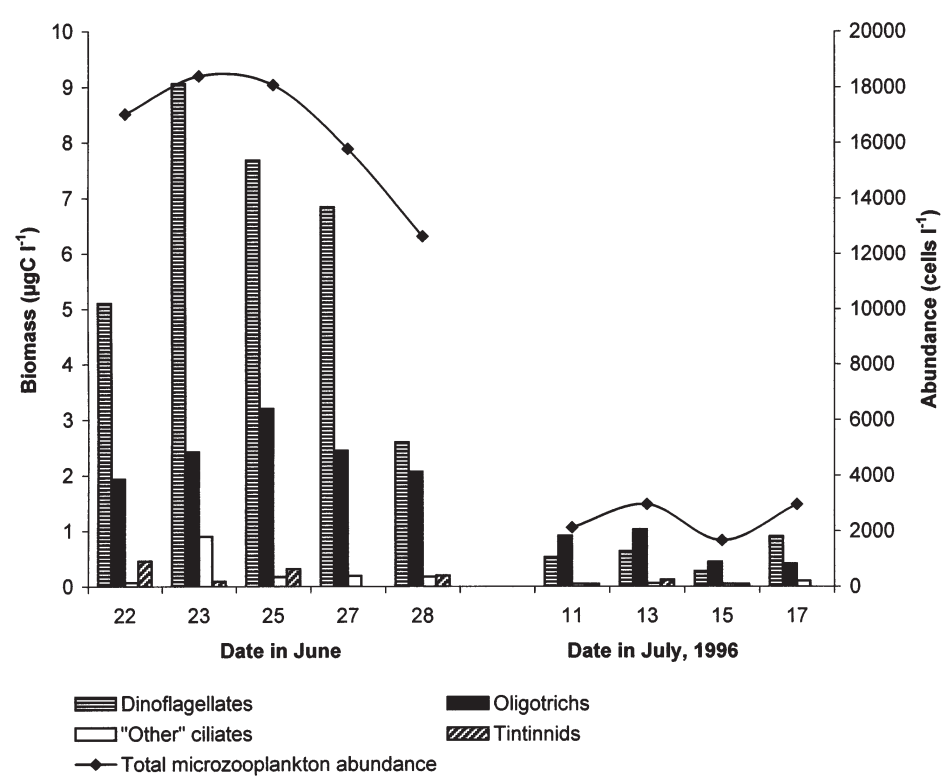

Fig. 2. Mean biomass of 4 main categories of the microzooplankton fraction and total cell concentration, excluding the HNAN, recorded in initial experimental water 
Table 2. Comparison of apparent phytoplankton growth $(k)$ and mortality $(g)$ rates and microzooplankton herbivory on daily chlorophyll (Chl) standing stocks measured by dilution technique in this and previous studies. -: not published

\begin{tabular}{|c|c|c|c|c|c|c|}
\hline Region & Month & $\begin{array}{l}\text { Growth } \\
k\left(\mathrm{~d}^{-1}\right)\end{array}$ & $\begin{array}{l}\text { Grazing } \\
g\left(\mathrm{~d}^{-1}\right)\end{array}$ & $\begin{array}{c}\text { Chl a turnover } \\
\%\left(\mathrm{~d}^{-1}\right)\end{array}$ & $\begin{array}{l}\text { Chl } a \\
\mu g l^{-1}\end{array}$ & Source \\
\hline $47^{\circ} \mathrm{N}, 18^{\circ} \mathrm{W}$ & May & $0.59-0.97$ & $0.56-0.76$ & $43-53$ & $2.0-4.0$ & Verity et al. (1993) \\
\hline $60^{\circ} \mathrm{N}, 20^{\circ} \mathrm{W}$ & Jun & - & 0.33 & 27 & 0.97 & Burkill et al. (1993) \\
\hline $56^{\circ} \mathrm{N}, 20^{\circ} \mathrm{W}$ & Jun & - & 0.60 & 45 & 0.44 & Burkill et al. (1993) \\
\hline $52^{\circ} \mathrm{N}, 20^{\circ} \mathrm{W}$ & Jun & $0.46-0.5$ & $0.26-0.36$ & $23-30$ & $1.33-1.69$ & Burkill et al. (1993) \\
\hline $47^{\circ} \mathrm{N}, 20^{\circ} \mathrm{W}$ & Jul & $0.21-0.67$ & $0.36-0.57$ & $29-43$ & $1.27-1.46$ & Burkill et al. (1993) \\
\hline $60^{\circ} \mathrm{N}, 20^{\circ} \mathrm{W}$ & Jun & $1.24-1.7$ & $0.89-1.48$ & $59-77$ & $0.94-1.26$ & This study \\
\hline $59^{\circ} \mathrm{N}, 19^{\circ} \mathrm{W}$ & Jun & 1.62 & 1.34 & 74 & 0.61 & This study \\
\hline $37^{\circ} \mathrm{N}, 19^{\circ} \mathrm{W}$ & Jul & $0.7-1.14$ & $0.26-0.57$ & $23-43$ & $0.05-0.07$ & This study \\
\hline $59^{\circ} \mathrm{N}, 21^{\circ} \mathrm{W}$ & May & $0.13-0.87$ & $0.83-1.01$ & $56-64^{\mathrm{a}}$ & $0.59-2.89$ & Gifford et al. (1995) \\
\hline $59^{\circ} \mathrm{N}, 21^{\circ} \mathrm{W}$ & Aug & $0.3-0.45$ & $0.11-0.24$ & $10-21$ & $1.19-1.8$ & Gifford et al. (1995) \\
\hline Sargasso Sea & Mar-Oct & $0.08-0.75$ & $0.28-0.71$ & $25-56^{b}$ & $0.04-1.05$ & Lessard \& Murrell (1998) \\
\hline Gulf of Mexico & May & 0.46 & 0.15 & $14^{\mathrm{c}}$ & 0.21 & Strom \& Strom (1996) \\
\hline \multicolumn{7}{|c|}{$\begin{array}{l}{ }^{\mathrm{a}}>20 \mu \mathrm{m} \text { chlorophyll } \\
{ }^{\mathrm{b}} \text { Oligotrophic and nutrient-limiting } \\
{ }^{\mathrm{c}} \text { Oligotrophic waters }\end{array}$} \\
\hline
\end{tabular}

viously recorded in the temperate NE Atlantic during the spring (Verity et al. 1993) and summer (Burkill et al. 1993, Sleigh et al. 1996) periods. However, in contrast to the findings of our study, aloricate ciliates dominated at $60^{\circ} \mathrm{N}$ during the summer of 1989 (Burkill et al. 1993) and $59^{\circ} \mathrm{N}$ during the spring and summer periods in 1991 (Gifford et al. 1995). Nevertheless, variations in the fixation methods used could account for the discrepancy between these data through the potential losses of ciliates (Stoecker et al. 1994a). In the

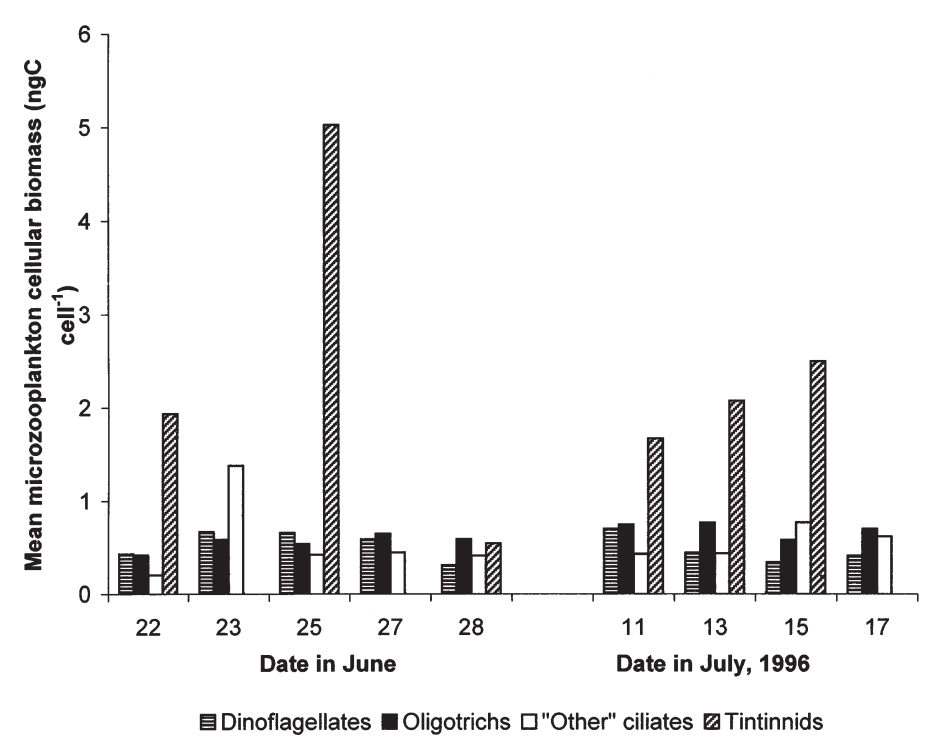

Fig. 3. Size composition of 4 main categories of the microzooplankton fraction, excluding the HNAN, expressed as carbon biomass per individual grazer, recorded in initial replicate experimental water samples southerly waters, microzooplankton abundance was on average $85 \%$ lower than in northerly waters, and HNAN and oligotrich ciliates were the major herbivores. This is typical of oligotrophic communities (Strom \& Strom 1996, Stelfox et al. 1999), as the dominant picoplankton groups may be too small for efficient grazing by some dinoflagellates. This shift in the microzooplankton community structure appeared to be clearly associated with a shift in the phytoplankton community from nanoflagellates and a bloom of coccolithophores in the northerly waters to a dominance of picoplankton in the southerly waters.

Growth rates of phytoplankton, estimated from our experiments, were generally higher than those previously recorded for the NE Atlantic and other sub-tropical regions (Table 2). Estimates of the apparent growth of phytoplankton in the northerly waters $\left(>1 \mathrm{~d}^{-1}\right)$ were almost double those recorded at $47^{\circ} \mathrm{N}$ during the 1989 spring bloom (Verity et al. 1993) and at $59^{\circ} \mathrm{N}$ in 1991 (Gifford et al. 1995). We attribute this to the fast growth response of Coccolithus pelagicus, which were smaller in cell size than previously found in other populations and suggests that they were rapidly dividing (D. Harbour pers. comm.). At the southerly station, our phytoplankton growth estimates appeared at first sight to be considerably higher than growth rates recorded in oligotrophic conditions in the Sargasso Sea (Lessard \& Murrell 1998) and the Gulf of Mexico (Strom \& Strom 1996). In fact, our lowest growth rates seemed similar to the highest rates recorded in the Sargasso Sea (Lessard \& Murrell 1998). However, since our 
initial growth rates were overestimated by approximately $32 \%$ due to photoadaptation (Perry et al. 1981), the corrected values (Table 1) were in fact similar to rates previously recorded in the oligotrophic Sargasso Sea (Lessard \& Murrell 1998) and Gulf of Mexico (Strom \& Strom 1996).

Our estimates of microzooplankton specific grazing rates during the northerly study, inferred by $g$, were also higher than those in comparable studies. Our lowest estimates exceeded the highest grazing rates reported between 47 and $60^{\circ} \mathrm{N}$ during spring and summer 1989 (Burkill et al. 1993, Verity et al. 1993) and were similar to the highest rates recorded in 1991 by Gifford et al. (1995). It is possible that grazing rates may have been overestimated if the microzooplankton were rapidly dividing in response to the high concentration and growth rates of coccolithophores and nanoflagellates. In this situation, microzooplankton population densities would increase at a faster rate in the undiluted samples, where phytoplankton concentration was higher (Landry et al. 1995). We did not quantify the microzooplankton community structure in each dilution sample, nor at the end of each experiment, and therefore cannot comment on changes in predator densities and how these may have affected our grazing rates. However, it may be difficult to determine small changes in predator concentrations because of the error of the counting method (Gifford 1988). For example, the average coefficient of variation for cell counts on initial undiluted water samples from this study are $15 \%$ for all microzooplankton, $24 \%$ for heterotrophic dinoflagellates and $16 \%$ for oligotrich ciliates. Verity et al. (1993) measured changes in the relative densities of the microzooplankton during $24 \mathrm{~h}$ incubations at $47^{\circ} \mathrm{N}$ during May 1989 and reported that growth rates of ciliates and dinoflagellates were highly variable (e.g. dinoflagellates -0.2 to +0.3 , ciliates -1.7 to $+0.4 \mathrm{~d}^{-1}$ ). They concluded that growth of ciliates and dinoflagellates were coupled with mortality of HNAN, suggesting that changes in the relative densities of microzooplankton were complicated by trophic interactions between microbial predators. Whilst nutrient limitation in our experimental incubations may have led to an overestimation of grazing and underestimation of growth (Gifford 1988), there was no evidence of negative growth in the undiluted treatments. Since grazing did not exceed growth in any of our experiments it seems unlikely that nutrient limitation occurred.

The vigorous grazing activity of the microzooplankton, measured during our northerly study, accounted for a turnover of $71 \% \mathrm{~d}^{-1}(\mathrm{SD}=7 \%)$ of the chlorophyll standing stock (Table 3). This represented a flux of between 18 and $37 \mathrm{\mu g} \mathrm{Cl}^{-1} \mathrm{~d}^{-1}$ which, when compared to the daily rates of primary production $(24.3$ to $50.5 \mu \mathrm{g}$ $\mathrm{C}^{-1} \mathrm{~d}^{-1}$; Rees et al. 2001), indicated that microzooplankton grazed between 65 and $167 \%$ of the daily phytoplankton production.

During the southerly study, microzooplankton specific grazing rates were similar to estimates from the oligotrophic Sargasso Sea (Lessard \& Murrell 1998), but slightly higher than values recorded in the Gulf of Mexico (Strom \& Strom 1996). Grazing steadily decreased over the $7 \mathrm{~d}$ period, which coincided with an increase in Prochlorococcus spp. abundance (Tarran et al. 2001). Whilst it is likely that the HNAN are the most important grazers of picoplankton in this and other regions, a recent study by Christaki et al. (1999) suggested that Prochlorococcus spp. are less actively grazed by ciliates than Synechococcus spp. A significant linear relationship $(p<0.05)$ showed that as the prochlorophyte population increased, the proportion of apparent phytoplankton growth lost to microzooplankton grazing decreased (Fig. 4) and may explain the observed decrease in grazing activity during the southerly study.

Table 3. Estimates of chlorophyll turnover $\left(P_{\mathrm{i}}\right)$, carbon flux through ingestion rates $(I R)$ and proportion of daily primary production consumed by the microzooplankton $\left(P_{\mathrm{c}}\right) . \Delta \mathrm{PC}$ : daily photosynthetic rate from ${ }^{14} \mathrm{C}$ productivity measurements (Donald et al. 2001, Rees et al. 2001). IR calculated assuming C:chlorophyll $a$ of 40 at $60^{\circ} \mathrm{N}$ and 180 at $37^{\circ} \mathrm{N}$ (chlorophyll a from Table 1)

\begin{tabular}{|lccccc|}
\hline Date (1996) & Latitude $^{\circ} \mathrm{N}$ & Longitude ${ }^{\circ} \mathrm{W}$ & $P_{\mathrm{i}}\left(\% \mathrm{~d}^{-1}\right)$ & $I R\left(\mu \mathrm{C} \mathrm{l}^{-1} \mathrm{~d}^{-1}\right)$ & $P_{\mathrm{c}}=\frac{I R}{\Delta \mathrm{PC}}\left(\% \mathrm{~d}^{-1}\right)$ \\
\hline 22 Jun & 59.201 & 20.122 & 59 & 28.4 & 167 \\
23 Jun & 58.968 & 20.021 & 73 & 36.9 & 79 \\
24 Jun & 59.143 & 20.733 & 71 & 28.9 & 80 \\
27 Jun & 58.988 & 20.668 & 74 & 30.9 & 18.0 \\
28 Jun & 59.093 & 19.448 & 44 & 3.8 & 228 \\
11 Jul & 37.008 & 19.001 & 42 & 3.3 & 101 \\
13 Jul & 36.922 & 19.212 & 23 & 2.6 & 35 \\
15 Jul & 36.691 & 19.225 & & \\
17 Jul & 36.319 & 19.150 & & \\
\hline
\end{tabular}




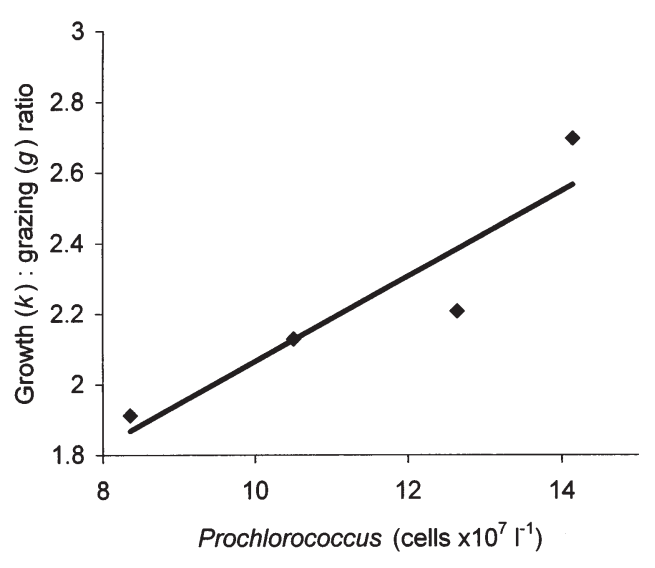

Fig. 4. Relationship between Prochlorococcus spp. cell concentration and the proportion of daily phytoplankton growth lost to grazing $(k: g)$. Equation of the regression line is $y=$ $0.1209 x+0.8565, r^{2}=0.85, n=4$

Grazing in the southerly waters accounted for $35 \%$ $\mathrm{d}^{-1}(\mathrm{SD}=9 \%)$ of the phytoplankton stocks and a flux of 3 to $4 \mu \mathrm{g} \mathrm{Cl}^{-1} \mathrm{~d}^{-1}$. Comparison of the grazing rates with parallel measurements of ${ }^{14} \mathrm{C}$ primary production (1.9 to $7.4 \mu \mathrm{C} \mathrm{C}^{-1} \mathrm{~d}^{-1}$, Donald et al. 2001) suggests that microzooplankton grazing exceeded phytoplankton production $(>200 \%)$ in the southerly waters, in contrast to the estimates of phytoplankton growth and mortality from the dilution experiments. Estimates of this kind are strongly influenced by carbon to chlorophyll a ratios. We used a factor of 40 for the experiments conducted in the northerly study (Verity et al. 1993) and 180 for the southerly study (Buck et al. 1996). However, a C:chlorophyll a value of 180 may not be representative of our southerly site. C:chlorophyll $a$ ratios are sensitive to depth and latitude, and considering that the experiments were sampled from the $33 \%$ surface irradiance level, we quantified phytoplankton growth in water at or below the surface mixed layer. Applying a lower C:chlorophyll a conversion value of 100 suggests that on average $70 \%$ (range between 19 and $128 \%$ ) of the daily primary production was grazed by the microzooplankton, which is in better agreement with our estimates of lower trophic coupling between growth and grazing in the southerly than northerly waters estimated from the dilution experiments.

Fig. 5 demonstrates the uncoupling between production and consumption during this study and shows that a higher ratio, attributed to excess growth, was observed in the southerly region. In the northerly study, microzooplankton grazing $(g)$ accounted for between 71 and $91 \%$ of the apparent phytoplankton growth estimates $(k)$, but this decreased with decreasing latitude, suggesting that in the southerly waters the microzooplankton were less efficient at controlling phyto-

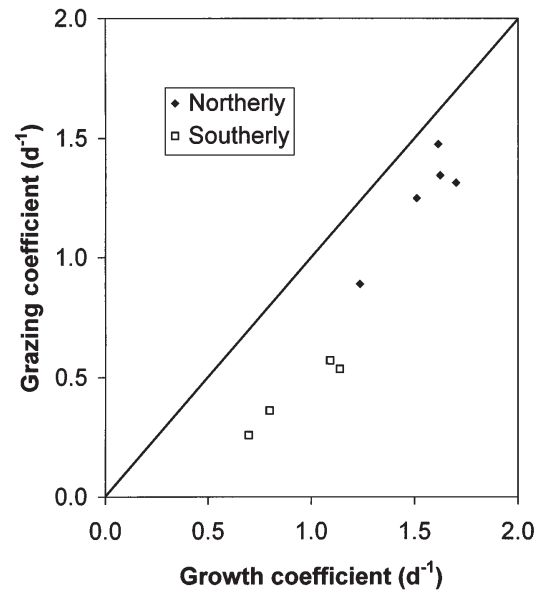

Fig. 5. Ratio between daily apparent phytoplankton growth and mortality (as grazing coefficient) rates, measured at northerly and southerly sites

plankton growth (average $46 \%, \mathrm{SD}=6 \%$ ). Despite corrections for photoadaptation in the southerly waters, grazing efficiency remained low and accounted for $<73 \%$ of the daily phytoplankton growth rates $\left(k_{c}\right)$. This is surprising, as one might expect tighter trophic coupling between microzooplankton and the small phytoplankton forms typical of oligotrophic conditions. Several other studies from oligotrophic areas (Landry et al. 1997, Latasa et al. 1997) have demonstrated a balance between phytoplankton growth and loss through grazing. Excess growth often occurs in areas dominated by larger phytoplankton, especially diatoms, which have particularly high growth rates (Strom \& Welschmeyer 1991, Latasa et al. 1997). However, Ferrier \& Rassoulzadegan (1991) reported that protozoan grazing may actually enhance in situ picoplankton specificgrowth rates by more than a factor of 2 through the regeneration of nutrients.

We compared our estimates of net phytoplankton growth $\left(\mu\right.$, as doublings $\left.\mathrm{d}^{-1}\right)$ with estimates of phytoplankton growth derived from parallel ${ }^{14} \mathrm{C}$ primaryproduction incubations (Donald et al. 2001, Rees et al. 2001) (as described by Harrison et al. 1982), and the results are presented in Table 4 . The data show that in the northerly waters, net phytoplankton growth from the dilution experiments is similar but slightly lower than that estimated from primary production. This is not surprising, as the measurements of ${ }^{14} \mathrm{C}$-derived phytoplankton production fall between the gross and net production (Donald et al. 2001). In contrast, our initial estimates of net phytoplankton growth $(k-g)$, at the southerly site, were considerably higher than those estimated using the primary-productivity method. However, corrections for photoadaptation showed that in fact net phytoplankton growth rates $\left(k_{c}-g\right)$ at the 
Table 4. Comparison of net phytoplankton growth rates $\left(\mu\right.$ doublings $\left.\mathrm{d}^{-1}\right)$ from dilution experiments and ${ }^{14} \mathrm{C}$ productivity measurements (data from Donald et al. 2001, Rees et al. 2001). ( $k-g$ and $k_{c}-g$ data from Table 1$)$. PC: phytoplankton carbon; $\Delta$ PC: daily photosynthetic rate. PC calculated assuming C:chlorophyll $a$ of 40 at $60^{\circ} \mathrm{N}$ and 180 and $37^{\circ} \mathrm{N}$ (chlorophyll $a$ data from Table 1 ). -: no evidence of photoadaptation, therefore not determined

\begin{tabular}{|c|c|c|c|c|c|}
\hline $\begin{array}{l}\text { Date } \\
\text { (1996) }\end{array}$ & $\begin{array}{l}\text { Latitude } \\
{ }^{\circ} \mathrm{N}\end{array}$ & $\begin{array}{l}\text { Longitude } \\
{ }^{\circ} \mathrm{W}\end{array}$ & $\begin{array}{c}\mu=\frac{(k-g)}{\ln 2} \\
\left(\text { doublings d }^{-1}\right)\end{array}$ & $\begin{array}{c}\mu=\frac{\left(k_{c}-g\right)}{\ln 2} \\
\left(\text { doublings d } d^{-1}\right)\end{array}$ & $\begin{aligned} \mu= & \log _{2}\left(\frac{\mathrm{PC}+\Delta \mathrm{PC}}{\mathrm{PC}}\right) \\
& \left(\text { doublings d }^{-1}\right)\end{aligned}$ \\
\hline 22 Jun & 59.201 & 20.122 & 0.50 & - & 0.54 \\
\hline 23 Jun & 58.968 & 20.021 & 0.56 & - & 0.43 \\
\hline 24 Jun & 59.143 & 20.733 & 0.20 & - & 0.60 \\
\hline 27 Jun & 58.988 & 20.668 & 0.38 & - & 0.57 \\
\hline 28 Jun & 59.093 & 19.448 & 0.40 & - & 0.64 \\
\hline $11 \mathrm{Jul}$ & 37.008 & 19.001 & 0.75 & 0.31 & 0.39 \\
\hline $13 \mathrm{Jul}$ & 36.922 & 19.212 & 0.87 & 0.29 & 0.36 \\
\hline $15 \mathrm{Jul}$ & 36.691 & 19.225 & 0.63 & 0.23 & 0.39 \\
\hline $17 \mathrm{Jul}$ & 36.319 & 19.150 & 0.63 & 0.25 & 0.50 \\
\hline
\end{tabular}

southerly study were comparable with the estimates of ${ }^{14} \mathrm{C}$-derived phytoplankton growth rates from the parallel primary-production experiments.

The vigorous grazing activity of the microzooplankton during this study suggests strong coupling between phytoplankton production and consumption, particularly at the northerly study. This would indicate that the grazing activity of mesozooplankton on phytoplankton production would, in comparison, be minimal. Head et al. (1999) demonstrated that mesozooplankton herbivory accounted for only $2 \%$ of the daily phytoplankton stocks at the northerly site and $6 \%$ at the southerly site. This reflects the tighter trophic coupling in northerly waters compared to the southerly waters, where uncoupling between phytoplankton growth and microzooplankton grazing was emphasised by higher mesozooplankton grazing of the phytoplankton stock. The low grazing impact of the mesozooplankton, particularly in the northern waters, suggests that phytoplankton consumption alone would not meet the nutritional requirements of the larger grazers for growth or egg production (Head et al. 1999, Irigoien et al. 2000). Therefore, while the mesozooplankton will consume a small proportion of the phytoplankton stocks and hence contribute to export flux from the euphotic zone, they will also graze on the microzooplankton and detritus and thus export organic material via a multiple-step process. These findings are similar to those reported for the temperate northeast Atlantic during spring (Gifford et al. 1995) and summer (Morales et al. 1991, Burkill et al. 1993).

We therefore conclude that microzooplankton were important grazers of phytoplankton in the northern, temperate waters of the NE Atlantic during the summer, which suggests strong coupling between production and consumption. Our findings support those previously reported for this region (Burkill et al. 1993,
Verity et al. 1993, Weeks et al. 1993, Gifford et al. 1995). During the southerly study, we observed high phytoplankton growth rates which were not matched by phytoplankton mortality, suggesting that microzooplankton were not controlling phytoplankton production. However, because of lower incubation light levels, photoadaptation, caused an overestimation of apparent phytoplankton growth rates in our experiments. Despite making corrections for this our data still suggest trophic uncoupling between microzooplankton and phytoplankton at or below the surface mixed layer during our southerly study. This coincided with an increase in Prochlorococcus spp. abundance, and infers that microzooplankton were not capable of controlling the production of prochlorophytes in the oligotrophic sub-tropical NE Atlantic during the summer.

Acknowledgements. We thank the scientists, officers and crew of RRS 'Discovery' and Chief Scientist, Graham Savidge. We also wish to thank Andy Rees, Kirsten Donald and Ian Joint for help with primary production data. This work was funded by the Natural Environment Research Council (NERC) PRIME Special Topic Grant GST/02/1065 and forms part of the CCMS Plymouth Marine Laboratory's DYME Programme. This is the PRIME publication number 123.

\section{LITERATURE CITED}

Aiken J (1981) A chlorophyll sensor for automatic, remote, operation in the marine environment. Mar Ecol Prog Ser 4:235-239

Anderson T (1997) Pelagic nutrient cycles, herbivores as sources and sinks. Springer-Verlag, Berlin, p 207-213

Atkinson A (1996) Subantarctic copepods in an oceanic, low chlorophyll environment: ciliate predation, food selectivity and impact on prey populations. Mar Ecol Prog Ser 130: 85-96

Børsheim KY, Bratbak G (1987) Cell volume to cell carbon conversion factors for a bacterivorous Monas sp. enriched from seawater. Mar Ecol Prog Ser 36:171-175 
Buck KR, Chavez FP, Campbell L (1996) Basinwide distributions of living carbon components and the inverted trophic pyramid of the central gyre of the North Atlantic Ocean, summer 1993. Aquat Microb Ecol 10:283-298

Burkill PH, Edwards ES, John AWG, Sleigh MA (1993) Microzooplankton and their herbivorous activity in the northeastern Atlantic Ocean. Deep-Sea Res (II) 40:479-493

Capriulo GM, Sherr EB, Sherr BF (1991) Trophic behaviour and related community feeding activities of heterotrophic marine protists. In: Reid PC, Turley CM, Burkill PH (eds) Protozoa and their role in marine processes. Springer-Verlag, Berlin, p 219-265 (NATO ASI Ser G 25)

Christaki U, Jacquet S, Dolan JR, Vaulot D, Rassoulzadegan F (1999) Growth and grazing on Prochlorococcus and Synechococcus by two marine ciliates. Limnol Oceanogr 44: $52-61$

Colebrook JM (1982) Continuous plankton records: seasonal variations in the distribution and abundance of plankton in the North Atlantic Ocean and the North Sea. J Plankton Res 4:435-462

Donald KM, Joint I, Rees AP, Woodward EMS, Savidge G (2001) Uptake of carbon, nitrogen and phosphorus by phytoplankton along the $20^{\circ} \mathrm{W}$ meridian in the NE Atlantic between $56.5^{\circ} \mathrm{N}$ and $37^{\circ} \mathrm{N}$. Deep-Sea Res (II) 48:885-909

Ducklow HG, Harris RP (1993) Introduction to the JGOFS North Atlantic Bloom Experiment. Deep-Sea Res (II) 40:1-8

Ferrier C, Rassoulzadegan F (1991) Density-dependent effects of protozoans on specific growth rates in pico- and nanoplanktonic assemblages. Limnol Oceanogr 36: 657-669

Gifford DJ (1988) Impact of grazing by microzooplankton in the Northwest Arm of the Halifax Harbour, Nova Scotia. Mar Ecol Prog Ser 47:249-258

Gifford DJ, Fessenden LM, Garrahan PR, Martin E (1995) Grazing by microzooplankton and mesozooplankton in the high-latitude North Atlantic Ocean: spring versus summer dynamics. J Geophys Res 100:6665-6675

Goldman JC, Caron DA, Dennett MR (1987) Nutrient cycling in a microflagellate food web chain. IV. Phytoplanktonmicroflagellate interactions. Mar Ecol Prog Ser 38:75-87

Harrison WG, Platt T, Irwin B (1982) Primary production and nutrient assimilation by natural phytoplankton populations of the Eastern Canadian Arctic. Can J Fish Aquat Sciences 39:335-345

Head RN, Harris RP, Bonnet D, Irigoien X (1999) A comparative study of size fractionated mesozooplankton and grazing in the North East Atlantic. J Plankton Res 21: $2285-2308$

Irigoien X, Harris RP, Head RN, Lindley A, Harbour DS (2000) Physiology and population structure of Calanus finmarchicus (Copopoda: Calanoida) during a Lagrangian tracer release experiment in the North Atlantic. J Plankton Res 22:205-221

Joint IR, Pomroy A, Savidge G, Boyd P (1993) Size fractionated primary productivity in the North East Atlantic in spring 1989. Deep-Sea Res (II) 40:423-440

Landry MR, Hassett RP (1982) Estimating the grazing impact of marine micro-zooplankton. Mar Biol 67:283-288

Landry MR, Kirshtein J, Constantinou J (1995) A refined dilution technique for measuring the community grazing impact of microzooplankton, with experimental tests in the central equatorial Pacific. Mar Ecol Prog Ser 120:53-63

Landry MR, Barber RT, Bidigare RR, Chai F, Coale KH, Dam HG, Lewis MR, Lindley ST, McCarthy JJ, Roman MR, Stoecker DK, Verity PG, White JR (1997) Iron and grazing constraints on primary production in the central equatorial Pacific: an EqPac synthesis. Limnol Oceanogr 42:405-418
Latasa M, Landry, MR, Schlüter L, Bidigare RR (1997) Pigment-specific growth and grazing rates of phytoplankton in the central equatorial Pacific. Limnol Oceanogr 42: $289-298$

Law CS, Liddicoat MI, Martin AP, Richards KJ (2001) A Lagrangian SF6 tracer study of an anticyclonic eddy in the North Atlantic. Deep-Sea Res (II) 48:705-724

Lessard EJ (1991) The trophic role of heterotrophic dinoflagellates in diverse marine environments. Mar Microb Food Webs 5:49-58

Lessard EJ, Murrell MC (1998) Microzooplankton herbivory and phytoplankton growth in the northwestern Sargasso Sea. Aquat Microb Ecol 16:173-188

Martin AP, Wade IP, Richards KJ, Heywood KJ (1998) The PRIME Eddy. J Mar Res 56:439-462

Martin AP, Richards KJ, Law CS, Liddicoat M (2001) Horizontal dispersion within an anticyclonic mesoscale eddy. Deep-Sea Res (II) 48:751-767

Michaels AF, Silver MW (1988) Primary production, sinking fluxes and the microbial food web. Deep-Sea Res 35: 473-490

Morales CE, Harris RP, Head RN, Tranter PRG (1991) Copepod grazing in the oceanic northeast Atlantic during a six week drifting station: the contribution of size classes and vertical migrants. J Plankton Res 15:185-211

Perry MJ, Talbot MC, Alberte RS (1981) Photoadaptation in marine phytoplankton: response of the photosynthetic unit. Mar Biol 62:91-101

Putt M, Stoecker DK (1989) An experimentally determined carbon:volume ratio for marine 'oligotrichous' ciliates from estuarine and coastal waters. Limnol Oceanogr 34: 1097-1103

Rees AP, Joint I, Woodward EMS, Donald KM (2001) Carbon, nitrogen and phosphorous budgets within a mesoscale eddy: comparison of mass balance with in vitro determinations. Deep-Sea Res (II) 48:871-884

Savidge G, Williams PJ LeB (2001) The 1996 PRIME Cruise: an overview. Deep-Sea Res (II) (in press)

Sherr EB, Sherr BF, Paffenhöffer GA (1986) Phagotropic protozoa as food for metazoans: a 'missing' trophic link in marine pelagic food webs. Mar Microb Food Webs 1: $61-80$

Sieracki ME, Verity PG, Stoecker DK (1993) Plankton community response to sequential silicate and nitrate depletion during the 1989 North Atlantic spring bloom. DeepSea Res (II) 40:213-225

Sleigh MA, Edwards ES, John AWG, Burkill PH (1996) Microzooplankton community structure in the Northeastern Atlantic: trend with latitude, depth and date, between May and early August. J Mar Biol Assoc UK 76: 287-296

Stelfox CE, Burkill PH, Edwards ES, Harris RP, Sleigh MA (1999) The structure of zooplankton communities, in the 2 to $2000 \mu \mathrm{m}$ size range, in the Arabian Sea during and after the SW Monsoon, 1994. Deep-Sea Res (II) 46:815-842

Stoecker DK, Gifford DJ, Putt M (1994a) Preservation of marine planktonic ciliates: losses and cell shrinkage during fixation. Mar Ecol Prog Ser 110:293-299

Stoecker DK, Sieraki ME, Verity PG, Michaels AE, Haugen E, Burkill PH, Edwards ES (1994b) Nanoplankton and protozoan microzooplankton during the JGOFS North Atlantic Bloom Experiment: 1989 and 1990. J Mar Biol Assoc UK 74:427-443

Strom SL, Strom MW (1996) Microzooplankton growth, grazing, and community structure in the northern Gulf of Mexico. Mar Ecol Prog Ser 130:229-240

Strom SL, Welschmeyer NA (1991) Pigment-specific rates of 
phytoplankton growth and microzooplankton grazing in the open subarctic Pacific Ocean. Limnol Oceanogr 36: $50-63$

Tarran GA, Zubkov MV, Sleigh MA, Burkill PH, Yallop M (2001) Microbial community structure and standing stocks in the NE Atlantic in June and July of 1996. Deep-Sea Res (II) 48:963-985

Utermöhl H (1958) Zur Vervollkommnung der quantitativen Phytoplankton Methodik. Mitt Int Verein Theor Angew Limnol 9:1-38

Verity PG, Stoecker DK, Sieraki ME, Nelson JR (1993) Grazing, growth and mortality of microzooplankton during the 1989 North Atlantic spring bloom at $47^{\circ}, 18^{\circ} \mathrm{W}$. Deep-Sea Res 40:1793-1814

Wassmann P (1998) Retention versus export food chains: processes controlling sinking loss from marine pelagic systems. Hydrobiologia 363:29-57

Editorial responsibility: Mike Landry (Contributing Editor), Honolulu, Hawaii, USA
Weeks A, Conte MH, Harris RP, Bedo A, Bellan I, Burkill PH, Edwards ES, Harbour DS, Kennedy H, Llewellyn C, Mantoura RFC, Morales CE, Pomroy AJ, Turley CM (1953) The physical and chemical environment and changes in community structure associated with bloom evolution: the Joint Global Flux Study North Atlantic bloom experiment. Deep-Sea Res (II)40:347-368

Weisse T, Scheffel-Möser U (1991) Uncoupling the microbial loop: growth and grazing loss rates of bacteria and heterotrophic nanoflagellates in the North Atlantic. Mar Ecol Prog Ser 71:195-205

Woodward EMS, Rees AP (2001) Micro-nutrient and nanomolar ammonium distributions associated with the PRIME eddy. Deep-Sea Res (II) 48:787-805

Zubkov MV, Sleigh MA, Burkill PH (2001) Heterotrophic bacterial turnover along the $20^{\circ} \mathrm{W}$ meridian between $59^{\circ} \mathrm{N}$ and $37^{\circ} \mathrm{N}$ in July 1996 . Deep-Sea Res (II) 48:987-1001

Submitted: April 10, 1999; Accepted: June 22, 2000

Proofs received from author(s): November 8, 2000 